\title{
ヨーグルトに分散した気泡が誘電特性に及ぼす影響
}

\author{
井口 亮，川井清司，羽倉義雄 ${ }^{\dagger}$ \\ 広島大学大学院 生物圈科学研究科
}

\section{Effect of Dispersion Air Bubbles in Yogurt on Dielectric Properties}

\author{
Ryo INOKUCHI, Kiyoshi KAWAI, and Yoshio HAGURA ${ }^{\dagger}$ \\ Graduate School of Biosphere Science, Hiroshima University, \\ 1-4-4, Kagamiyama, Higashi-Hiroshima 739-8528, Japan
}

\begin{abstract}
The dielectric properties are related to other physical variables of a sample, such as its structure, composition, phase, and temperature. Therefore, an analytical method that uses these properties can be an effective means to determine the structure of a sample. In addition, nondestructive measurement is possible by this method. In this study, we attempted the nondestructive measurement of air bubbles in yogurt using dielectric properties, namely, complex electric capacitances. The samples were prepared by dispersing air bubbles in base yogurt. The effects of the air volume and the air bubble size in yogurts on dielectric properties were investigated. Consequently, the capacitance increased with an increase in air volume in yogurt. Moreover, the capacitance increased with decreasing diameter of air bubbles in yogurt. In this study, it was considered that the electrokinetic phenomenon generated at the interface of the gas and liquid phases contributed to the increase of the capacitance. The complex electric capacitances of the base yogurt and the air-mixed yogurt were measured in the range of $50 \mathrm{~Hz}-1 \mathrm{MHz}$. When a Cole-Cole plot was drawn from the measured data, a clear difference was seen in the sizes of the circular arcs of the two samples. In the frequency range of the circular arc locus of the Cole-Cole plot, the capacitance of air-mixed yogurt was always greater than that of the base yogurt. From the above-mentioned result, it was clarified that air bubbles in the yogurt could be quantified by measurement of the dielectric properties.
\end{abstract}

Keywords: yogurt, nondestructive measurement, dielectric properties, air bubble, electrokinetic phenomenon

1. 緒言

ヨーグルトは牛乳を原料として作製するため, カルシ ウム，タンパク質，脂質といった栄養成分が豊富に含ま れている。また，乳酸菌の働きにより牛乳の成分が一部 変化している.ヨーグルトのタンパク質は牛乳のタンパ ク質に比べて消化吸収が良いことが確認されており，そ の理由として主に，(1)乳酸菌が生成する酸により，力ゼ インのカードが微細となるため消化酵素による加水分解 を受けやすい. (2)乳酸菌によるタンパク加水分解により, アミノ酸やペプチドが増加している, などが挙げられる. また発酵乳の試験管内実験により，発酵による $\mathrm{pH}$ の低

(受付 2011 年 12 月 5 日，受理 2012 年 1 月 24 日) テ739-8528 広島県東広島市鏡山1-4-4

$\dagger$ Fax: 082-424-7938, E-mail: hagura@hiroshima-u.ac.jp
下も消化率に関与していることが明らかにされている [1]. さらに，発酵乳中の主要糖質である乳糖は乳酸菌 の発酵作用により，原料乳中の $30 \sim 40 \%$ が分解される. ヨーグルトでは残存乳糖も分解するため乳糖不耐症の人 でも容易に食べることができる [2].

このヨーグルトの製造工程には，発酵時における温 度，時間，酸度などの監視，スターターの製造，品質 検査など，多くの過程が存在する。近年 HACCP の観 点から，食品の品質が重視され，食品製造において機 械による自動化が進んでいる [3]. ヨーグルト製造にお いても上記の各工程で自動化が進み，安定した品質の 製品が製造可能となっている.

ヨーグルトにはプレーンヨーグルト，ハードヨーグ ルト，ドリンクヨーグルトなど，様々なタイプの製品 が存在する。これらの製造工程の各プロセスで使用さ れる機械・装置は様々であるが，それら機械間の輸送 
中ヨーグルトは液状の場合が多い。このように，ヨー グルトをはじめとした液状の食品の輸送にはパイプや ポンプを主に使用する [4-6]. このパイプ輸送の際，気 泡が混入する現象を泡噛み現象という。これが原因と なり製品に悪影響を及ぼす問題がある。例えばヨーグ ルトの製造工程に打いては，原料乳に気泡が混入する と加熱殺菌時の伝熱効率が低下するため殺菌効果が著 しく低下し，殺菌が不十分となってしまう [7]. また， とくにハードヨーグルトでは寒天やゼラチンにより ヨーグルトを凝固させ弾力性などの独特の食感を得て 扔り，気泡が混入することでざらざら感が出てしまう など, その商品価值が損なわれる可能性がある。一方で, 泡構造をもたせることでソフトな感触・食感や, 消化 器官での吸収効率の増加といった効果を付与すること も可能である [8]. このように食品への気泡の混入は 様々な影響を及ぼす。しかしながら，液状食品中に存 在する気泡の状態・量を定量的に評価する方法は十分 に確立されていない.

本研究では，混入した気泡の評価方法として電磁気 学的方法の 1 つである誘電特性を利用することにした。 誘電特性とは, 電場内で誘電体試料が示す特性であり, 誘電率, 誘電損失, 誘電緩和, 誘電分極などを指す. 誘電特性は測定試料中の特定の原子団や分子の運動状 態を直接反映しているために，測定試料中の成分分子 の状態や変化を検出する有効な手段となる [9].さらに, 非接触かつ連続的な測定が可能である点も利点として 挙げられる. 本研究ではヨーグルトを実験試料として 用い、ヨーグルト中に分散した気泡が誘電特性に与え る影響を調べ，誘電特性を利用した泡噛み現象の検出 のための基礎的な知見を得ることを目的とした。 とく に，ヨーグルトをカップに充填後，未開封のまま気泡 混入の有無を検出することを想定し，アクリル樹脂製
容器を用いて非接触での誘電特性測定を行った.

\section{2. 実験方法}

\section{1 試料調製}

市販のプレーンヨーグルト（明治乳業株式会社）お よびペクチン（SIGMA-ALDRICH 社）を試料として使 用した. 本実験ではヨーグルト内の気泡の有無が誘電 特性に与える影響を調べることを目的としている。そ のため，ヨーグルト中に気泡を分散させる必要がある. しかしヨーグルトのみを攪拌し液状化させた場合では 粘度が低く気泡をヨーグルト中に分散させることが困 難であった。そこで試料の粘度を調整する目的で乳製 品やゼリー，ジャムなどに広く使用されている増粘安 定剤であるぺクチンを使用した。

ホモジナイザ（特殊機化工業株式会社 TKロボミッ クス）を用いてヨーグルトを覮找しながら，ペクチン を $1 \mathrm{wt} \%$ となるように添加した。 このとき，ホモジナイ ザの回転数を $3000 \mathrm{rpm}$ に設定し, 20 分間攪找を行った. 攪拌中はヨーグルト中に気泡が入らないよう注意した. これを冷蔵庫内で一晚保存した後，3000 rpmで 5 分間 ホモジナイズした試料を気泡未混入試料（ベースヨー グルト)とした。一方, エアポンプに接続したエアストー ンを試料中に設置し，気泡を吹き込みながら $3000 \mathrm{rpm}$ で 5 分間摫拌および気泡の微細化を行った試料を気泡 混入試料とした。 また，気泡混合試料と気泡未混入試 料を同体積混合した試料も調製した。

\section{2 測定方法 \\ 2.2.1 実験装置}

実験装置の概略を Fig. 1 に示す. 外寸法 $(20 \mathrm{~cm} \times 20$ $\mathrm{cm} \times 1.08 \mathrm{~cm})$ のアクリル樹脂を加工し，平血状の試料

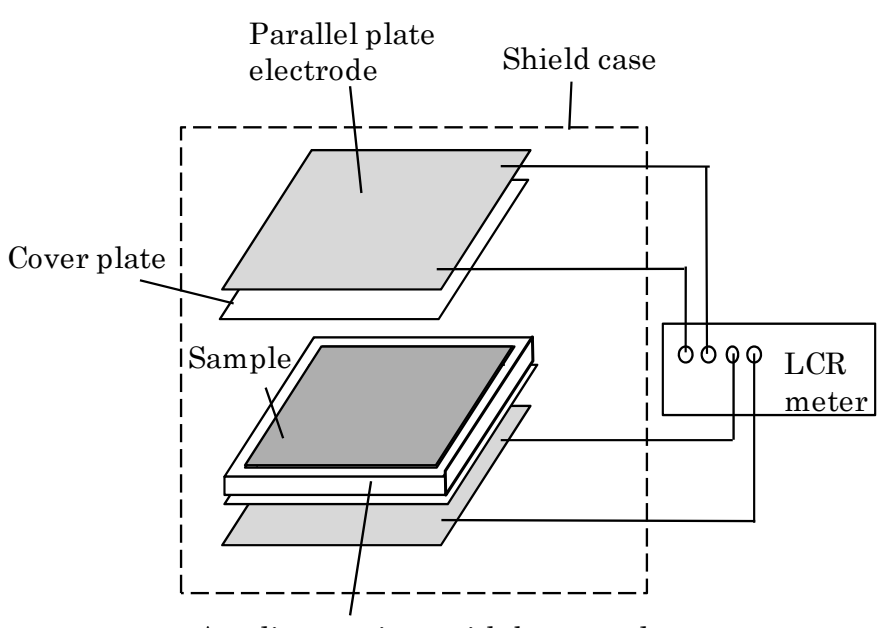

Acrylic container with bottom plate
Sample cell

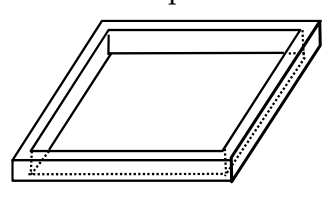

Sectional view

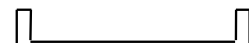

Fig. 1 Experimental apparatus for measuring dielectric properties. 
容器（内寸法: $19 \mathrm{~cm} \times 19 \mathrm{~cm} \times 1 \mathrm{~cm}$; 容器底面の厚さ： $0.08 \mathrm{~cm})$ を作製した。この容器を電極板 $(20 \mathrm{~cm} \times 20$ $\mathrm{cm} \times 0.1 \mathrm{~cm}) 2$ 枚で上下から挟み，これを誘電特性測 定用の試料セルとした。ただし，試料容器と上部電極 板との間には，絶縁のためアクリル樹脂製の蓋 $(20 \mathrm{~cm}$ $\times 20 \mathrm{~cm} \times 0.08 \mathrm{~cm})$ を設置した。試料セルの電極部分 をLCRメータ（日置電機株式会社 3522-50：測定周 波数 $1 \mathrm{mHz}-100 \mathrm{kHz}, 3532$ : 測定周波数 $45 \mathrm{~Hz}-5$ $\mathrm{MHz}$ )に接続し, 試料の誘電特性を測定した。測定の際, ノイズを防ぐため金属製のシールドケース $(45 \mathrm{~cm} \times 45$ $\mathrm{cm} \times 33 \mathrm{~cm})$ で実験装置全体を覆った。

\subsection{2 誘電特性測定}

調製した試料を試料容器に満たし，誘電特性の測定 を行った。電極板間距離は $1.16 \mathrm{~cm}$ であった。一般に, 誘電正接の值は小さいほど試料が理想的なコンデンサ であることを示し，大きいほど測定時にエネルギー損 失が生じていることを示す，本研究の測定では，周波 数約 $200 \mathrm{~Hz} \sim 100 \mathrm{kHz}$ の範囲で誘電正接は十分に小さ い值（0.05 以下）を示した。 また，単一の周波数で測 定值を示す場合には，代表值として周波数 $1 \mathrm{kHz}$ での 測定值を用いて実験結果を表した。測定は $4{ }^{\circ} \mathrm{C} に$ 設定し た恒温槽内で行った。各試料においてそれぞれ 4 回測 定を行った.

\section{3. 結果および考察}

\section{1 気泡量の測定}

電子天秤を用いて各試料の重量を測定した。本実験 では，気泡未混入試料を試料容器に満たした時の重量 の平均值を試料容器充填率 $100 \%$ の状態とし, 重量比で それぞれの試料の充填率を表した。 各試料の測定重量, 充填率および気泡含有率を Table 1 に示す，気泡混入試 料と気泡未混入試料を比較すると，気泡混入試料では 平均して単位体積当たり約 $24 \%$ の空気が存在していた.
両試料を混合した試料では単位体積当たり約 $11 \%$ の空 気が存在していた.

\section{2 気泡含有量が静電容量に及ぼす影響}

ヨーグルトに混入した気泡の量が静電容量に与える 影響について検討するため，気泡未混入試料および気 泡混入試料の静電容量をそれぞれ測定した。ささらに， 気泡未混入試料と気泡混入試料を混合し気泡の量をコ ントロールした試料についても同様に静電容量の測定 を行った. 測定結果を Fig. 2 に示す. ヨーグルトへの 気泡の混入量の増加に伴い静電容量は大きくなる傾向 を示した。また， $\mathrm{t}$ 検定を行ったところ気泡混入試料で は気泡未混入試料と比較して有意に静電容量が高かっ た $(p<0.05)$.

\section{3 気泡サイズが静電容量に及ぼす影響}

気泡混入試料は単位体積当たり約 $24 \%$ の空気が混入 していた。そこで，混入空気量を一定とし，試料中の

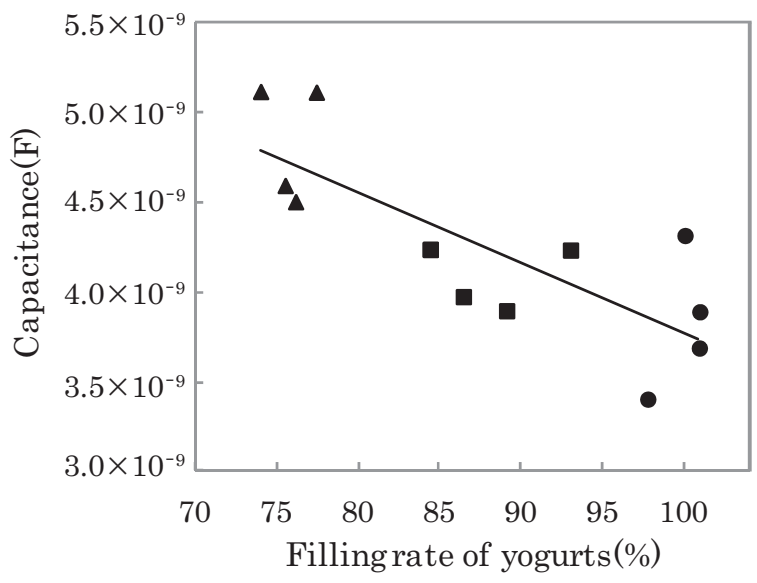

Fig. 2 Capacitance of sample yogurts. Base yogurt, Mixture of base yogurt and air mixed yogurt, $\mathbf{\Delta}$ : Air mixed yogurt. $R^{2}=0.6115$ )

Table 1 Weight, filling rate, and air bubbles content.

\begin{tabular}{lccc}
\hline $\begin{array}{c}\text { Sample } \\
\text { name }\end{array}$ & $\begin{array}{c}\text { air bubbles nonmixed yogurt } \\
\text { (Base yogurt) }\end{array}$ & $\begin{array}{c}\text { Mixture of base yogurt and } \\
\text { air mixed yogurt }\end{array}$ & $\begin{array}{c}\text { air bubbles mixed yogurt } \\
\text { (air mixed yogurt) }\end{array}$ \\
\hline Weight (g) & $330.30 \pm 2.48$ & $289.19 \pm 6.14$ & $250.48 \pm 2.35$ \\
\hline Filling rate(\%) & $100 \pm 0.75$ & $88.32 \pm 1.86$ & $75.84 \pm 0.71$ \\
\hline $\begin{array}{l}\text { air bubbles } \\
\text { content(\%) }\end{array}$ & 0 & $11.68 \pm 1.86$ & $24.16 \pm 0.71$ \\
\hline
\end{tabular}


分散気泡の大きさが静電容量に与える影響について検 討した. 気泡混入試料に加えて, 空気が気泡ではなく, 単なる空間として試料容器中に存在している場合，お よび気泡径を気泡混入試料よりも大きくした試料につ いて静電容量の測定を行った。具体的には，試料容器 体積の $76 \%$ を気泡未混入試料により満たし，残り $24 \%$ を空間 (空気) とした試料，および気泡混入の際ホモ ジナイズを行わず気泡を微細化しなかった試料を調製 し，静電容量の測定を行った。後者試料においては空 気の量は気泡混入試料と同様に気泡含有率が $24 \%$ とな るように気泡未混入試料を加えて調製した，気泡混入 試料および気泡を微細化しなかった試料については気 泡径を測定した. 微細な気泡については光学顕微鏡で, 目視で確認できる気泡については薬さじを用いて適量 試料を採取しノギスを用いて気泡径を測定した。その 結果, 気泡混入試料では約 $0.03 \sim 1 \mathrm{~mm}$, 気泡を微細化 しなかった試料では約 $0.5 \sim 3 \mathrm{~mm}$ の直径の気泡が存在 していた。それぞれの試料について 3 回の静電容量の 測定結果の (平均值) \pm (標準偏差) を Fig. 3 に示す. 統計処理にはWilliams 法を用いた。Fig. 3 では気泡 が微細化するのにしたがって静電容量が大きくなっ ている。

ある誘電体と誘電率を異にする別の誘電体が直列に 存在するときの静電容量 $\mathrm{C}_{s}$ は式（1）により，また， 誘電体中に誘電率を異にする別の誘電体が分散してい る場合の静電容量 $\mathrm{C}_{d}$ は式 (2) により求める事ができ る [10].

$$
\begin{gathered}
\mathrm{C}_{s}=\frac{S}{d} \times \varepsilon_{v} \times \frac{\varepsilon_{1} \varepsilon_{2}}{(1-\phi) \varepsilon_{2}+\phi \varepsilon_{1}} \\
\mathrm{C}_{d}=\frac{S}{d} \times \varepsilon_{v} \times \frac{2 \varepsilon_{1}+\varepsilon_{2}-2 \phi\left(\varepsilon_{1}-\varepsilon_{2}\right)}{2 \varepsilon_{1}+\varepsilon_{2}+\phi\left(\varepsilon_{1}-\varepsilon_{2}\right)} \varepsilon_{1}
\end{gathered}
$$

ここで, $S$ : 電極板面積 $\left[\mathrm{m}^{2}\right], d$ : 電極板間距離, $\varepsilon_{\nu}$ :

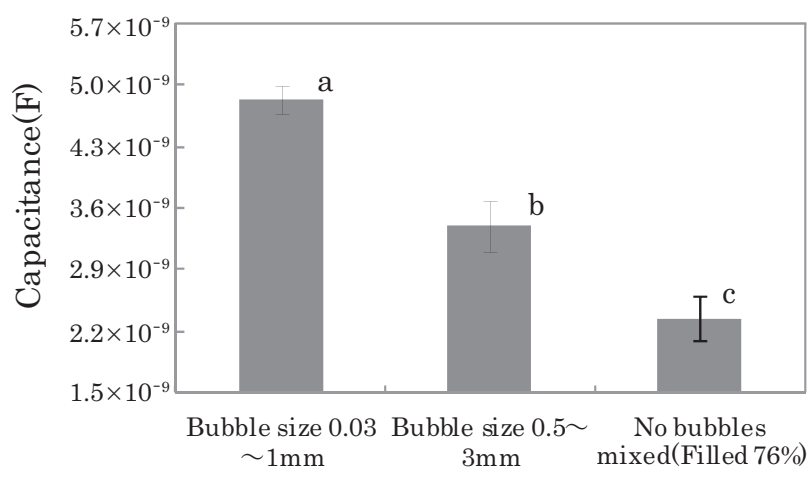

Fig. 3 Relationship between air bubble size and capacitance in sample yogurts $(n=3)$. Different letters indicate that the samples are considered significantly different at the level $p<0.05$.
真空の誘電率, $\varepsilon_{1}$ : 連続相の誘電率, $\varepsilon_{2}$ : 分散相の誘 電率, $\phi$ : 分散相の体積分率である. $\varepsilon_{1}$ を気泡未混入 試料の誘電率， $\varepsilon_{2}$ を空気の誘電率， $\phi$ を 0.24 として式 （1）を用いて静電容量を算出すると, 試料の静電容量 は $\mathrm{C}_{s}=1.24 \times 10^{-10} \mathrm{~F}$ となる。一方，式（2）を用いて同 様に静電容量を算出すると $\mathrm{C}_{d}=2.34 \times 10^{-9} \mathrm{~F}$ となる. 気 泡未混入試料を試料容器に $76 \%$ 満たした時の実測值は $2.35 \times 10^{-9} \mathrm{~F}$ であり, 式（2）から求めた值と概ね一致 している. 本研究で使用した試料容器は, その構造上, 蓋部分への試料の付着が避けられず，試料と空気が直 列に存在していない. この理由から，本研究における 静電容量の理論值の算出は式（2）が適していると考え られる. 試料容器へ満たす気泡未混入試料の量を変化 させた予備実験に打いても，測定結果が式（2）と一致 することを確認した，微細気泡がヨーグルト中に $24 \%$ 存在している場合の静電容量の実測值は約 $4.84 \times 10^{-9} \mathrm{~F}$ であり，理論值よりも大きかった，単位体積当たりの 空気量が一定であっても, 気泡径が小さくなるほど静 電容量が増加することがわかる.

Figs. 2,3より，ヨーグルト中に存在する気泡の量が 増加すると静電容量が大きくなること，また空気とヨー グルトの体積分率が同じであっても，気泡径が小さく なるのに伴い静電容量は大きくなることがわかった. 一般的に水分を多く含んだヨーグルトは空気よりも誘 電率が高く静電容量は大きい。このことから, 空気が ヨーグルトに混入すると静電容量は小さくなると予想 できる、しかしながら今回の実験結果では予想できる 結果と逆の傾向を示す結果となった. このような傾向 がみられた要因として, 界面動電現象による電気分極 が寄与していると考えられる.

微粒子が水溶液中に安定に分散しているとき，多く の場合粒子表面は正もしくは負の電荷を帯びている. このとき, 電気的中性を保つため溶液中の反対電荷が 表面近傍に集積する．荷電をもったこの層（固定層） を反対の荷電をもった層（拡散層）がさらに取り巻く ことで電気二重層構造ができる $[11,12]$. ここに電場を 印加すると，固定層と拡散層に作用する電気力の方向 はそれぞれ逆となり，界面をはさんだ両側で運動が発 生する。このような, 電荷を帯びた面が周囲の液体と 相対的に逆方向に移動するときの電気現象を界面動電 現象という [13].

微粒子と同様に, 液中に存在する気泡も電荷を帯び ており電気二重層を形成しているとされる，ただし固 体微粒子とは異なり，気泡の場合では電場印加したと き電荷面が気泡表面に固定されるという保証はない [13].ここで，ヨーグルト中に存在する $\beta$-カゼインを はじめとした可溶性球状タンパク質は，気一液界面に 吸着し気泡を安定化させることが知られている $[8,14]$. またA. Phianmongkholらは， $\beta$-カゼイン溶液中の気 


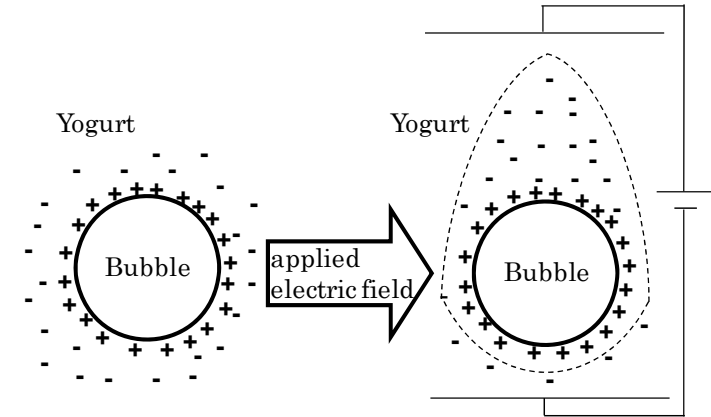

Fig. 4 Electrokinetic phenomenon of bubble in yogurt.

泡が電気泳動により正電極側に移動することを明らか にした [15]. 気泡表面に， $\beta$-カゼインなどのタンパク 質が吸着し，微粒子と同様な固定層を形成していると 推察できる。すなわち電場内において，ヨーグルト中 の気泡は固体微粒子のような挙動をとるといえる。た だし, 本研究で使用したヨーグルトは約 $\mathrm{pH}=4.2$ であり, 等電点 $\mathrm{pH}=4.6 \sim 5.1$ の $\beta$-カゼインは正に帯電してい ると考えられる。

界面導電現象により界面に存在する電荷が移動する と，気泡の負電極側に存在していた負電荷が不足し電位 差が発生する。このように，電気二重層は電場印加によ り気泡からずれて電気分極を生じる.ヨーグルト中の気 泡表面に存在する正に帯電した $\beta$-カゼインとその周囲の 反対電荷との間でも，同様に電気分極が生じると考えら れる（Fig. 4） [13]. また M. C. Zaghdoui らは，水中に 気泡が存在するとき，交流電場を印加すると気泡表面の 電荷が電界方向に応じて移動することを示した [16]. こ のように気泡は，電界の変化に追随する電気双極子，す なわち気泡表面の電気二重層は単純には球殼状コンデン サとみなせる。一般に，一定体積の空気が連続相に分散 している場合，気泡径が小さいほど気泡の総表面積は大 きくなる，試料内に存在する空気の体積が同じであって
も，気泡径が小さくなると気 - 液界面の面積が大きくな り電気二重層の面積が増加する.

この現象が気泡量の増加，すなわち気液界面積の増 加に伴い静電容量が高くなった要因と推察した.

\subsection{Cole-Cole プロットによる電極構造の評価}

誘電緩和挙動の特徴は測定試料により様々である. 複素誘電率や複素導電率を複素平面に表示する ColeCole プロットを行うことで誘電緩和の全体像を簡潔に 表すことができる。すなわち，Cole-Cole プロットでは 複素平面図中に表机る半円，円弧，直線などの誘電的 挙動の形によって経験的に測定試料の状態を捉えるこ とができる $[9,17]$.

本研究では気泡未混入試料と気泡混入試料の誘電特 性をアクリル製の試料セルを用いて測定した。誘電特 性測定值から求めた両試料の静電容量と複素静電容量 の Cole-Cole プロットを Fig. 5 に示す. Cole-Cole プ ロットの結果，気泡未混入試料では $111.8 \sim 6946 \mathrm{~Hz}$, 気泡混入試料では 86.34 $5366 \mathrm{~Hz}$ の間に大きな半円弧 がみられ，気泡混入試料では気泡未混入試料と比較し てょり細長い円弧となった。また，低周波数側では円 弧から外れ，上部へ直線的に伸びるプロットが，高周 波数側に打いては小さな円弧が崩れたようなプロット が得られた。プロットが円弧から外れて上部へ急激に 大きくなっていく有様はイオンによる電気伝導を表し ている [18]. ヨーグルト中に存在するイオンにより， 低周波数側で直線が現れたと推察した。また電極板間 に存在する試料が三相系である場合，誘電緩和は複数 表れることが知られている [9]．本研究の電極部の構造 は三相系であり，その電気的等価回路は Fig.6 (a) に より表現できる。ここで，アクリル樹脂製の試料容器 が存在せず測定試料が単相の場合の誘電緩和を調べる ため，液体測定電極（横河・ヒューレット・パッカー ド株式会社 HP 16452A）を用いて気泡未混入試料打よ び気泡混入試料の Cole-Cole プロットを行った．電極

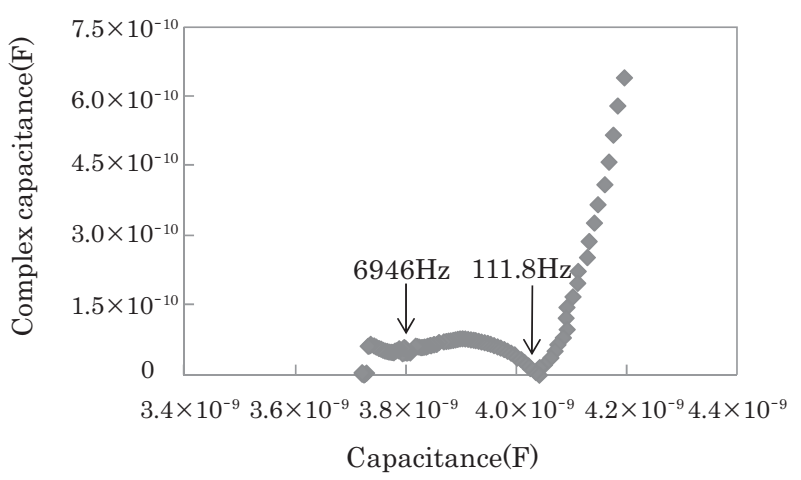

(a)

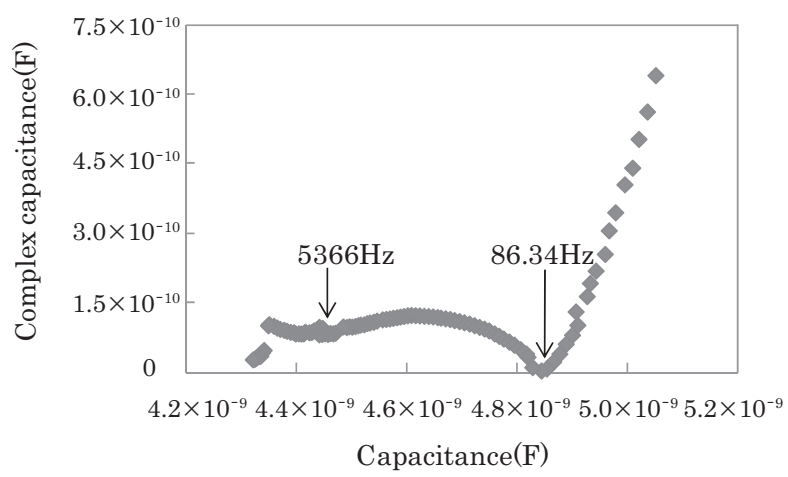

(b)

Fig. 5 The Cole-Cole plot of yogurts using acrylic container. (a)Base yogurt. (b)Air mixed yogurt. 


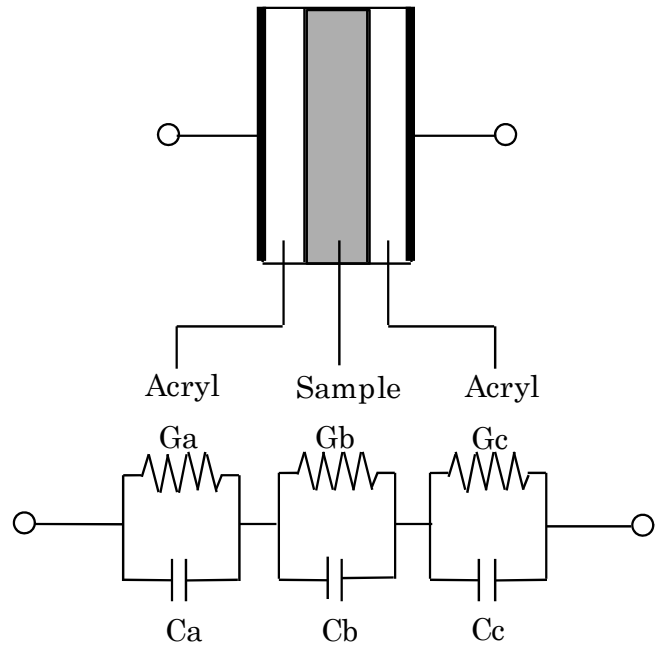

(a)

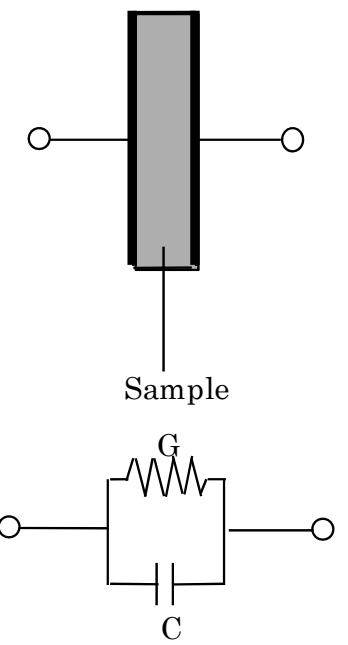

(b)

Fig. 6 The electrical equivalent circuit. (a) Acrylic container. (b) Electrodes for liquid.

板間距離は $2 \mathrm{~mm}$ とし， $4{ }^{\circ} \mathrm{C}$ に設定した恒温槽内で測定 を行った。その測定電極部の構造と電気的等価回路を Fig. 6 （b）に，測定結果を Fig. 7 に示す。アクリル樹 脂製の試料容器を用いた場合の測定結果と同様に，気 泡混入試料では気泡未混入試料よりも大きい円弧がみ られ，とくに低周波数側で高い静電容量を示していた. 一方で，高周波数側でみられた崩れた円弧は確認でき ず，誘電緩和は単一であった。すなわち Fig. 5 でみら れた，高周波数側の崩れた円弧はアクリル樹脂製の容 器の影響であると考えられる。また，気泡未混入試料 の $111.8 \sim 6946 \mathrm{~Hz}$ ，気泡混入試料の $86.34 \sim 5366 \mathrm{~Hz}$ の 間の大きな半円弧は試料の誘電緩和を表していると考 えられる。そこで，それぞれの半円弧が現れた周波数 帯域の静電容量を気泡未混入試料と気泡混入試料の間 で比較すると (Fig. 8)，静電容量は気泡混入試料の方 が常に大きい值を示した。したがって，この周波数帯
域内であれば 1 つの周波数を用いて静電容量を測定す ることにより気泡の混入の有無を判別できる可能性が ある。また，電極を直接試料と接触できない場合でも この周波数帯域内であれば容器などの影響を受けずに 測定が可能になると考えられる.

これらのことから，静電容量を用いることによりヨー グルトに混入した気泡の捕捉を非接触で行える可能性 を示すことができた。

\section{4. 結}

\section{論}

本研究では，ヨーグルト中に存在する気泡を誘電特 性を用いて捕捉する方法について検討した。その結果 以下の事項が明らかとなった。

1）ヨーグルト中に気泡が存在する場合静電容量は増加 し，さらに，気泡の量が増加するほど静電容量は大き

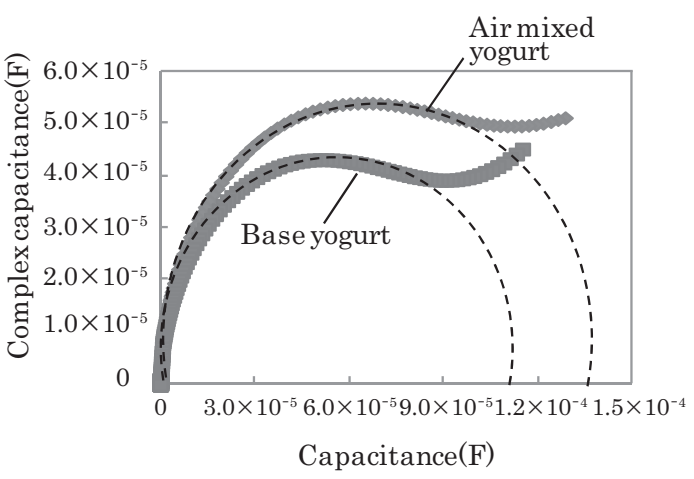

Fig. 7 The Cole-Cole plot of yogurts using electrodes for liquid.

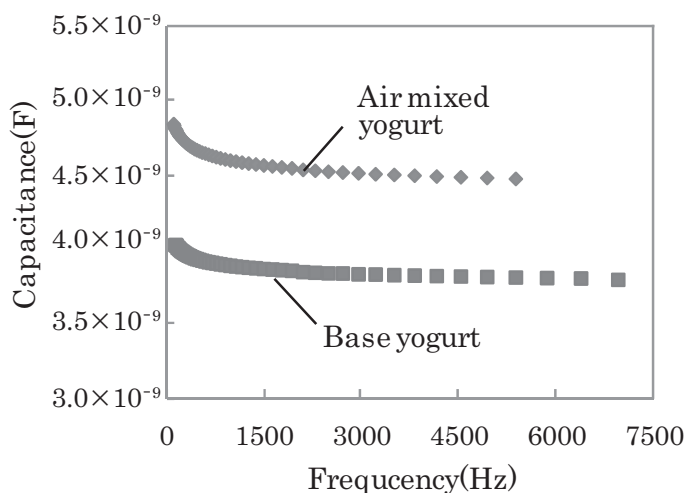

Fig. 8 Relationship between capacitance and frequency in the frequency range of the circular arc locus on Cole-Cole plot. 
くなる．2）ヨーグルト中に存在する気泡が微細になる， すなわち空気 - ヨーグルトの界面積が大きくなるにし たがって静電容量は増加する，3）Cole-Cole プロット の結果から，電極を直接試料と接触できない場合でも 容器などの影響を受けずに気泡の捕捉を行える可能性 を示すことができた。

以上のことから，誘電特性を用いる方法によりヨー グルトに混入した気泡の状態や量を捕捉できる可能性 が示されたといえる。しかしながら，ヨーグルト中に 存在する気泡についての詳細な挙動については十分に 解明できていない。 また，実際のヨーグルト製造現場 ではヨーグルトは流動状態にあり，さらに泡噛み現象 による気泡混入量は本実験と比較してより少ないと考 えられる。そこで今後の課題としては，フローセルを 用いた流動状態のヨーグルトの連続的な測定法の確立 や気泡の存在量が静電容量に及ぼす影響のより詳細な メカニズムの解明が必要である。

\section{謝辞}

本研究の一部は, 日本学術振興会 科学研究費補助金 (挑戦的萌芽研究) (研究課題番号 : 23658117) の援助 により行われた。また，測定用電極および試料セルの 製作・改良には，広島大学技術センター仲井敏技術班 長の助力を得た。ここに記して謝意を表す。

\section{引用 文 献}

1) Shokuhin sangyou onrain sensa gijutsu kenkyu kumiai; "Food industry and sensor (shokuhin sangyou to sensa)" Korinsha, Tokyo, Japan, 1991, pp.99-101, 110-111, 209.

2) K. Murao, K. Igaki, H. Hasegawa, T. Kaneko, H. Suzuki; "Differences in Breath Hydrogen Excretion and Abdominal Symptoms after Ingestion of Milk and Yogurt by Lactoseintolerant Individuals" (in Japanese), J. Jap. Soc. Nutr. Food Sci, 45, 507-512 (1992).

3) M. Yokoyama, K. Satomi, T. Yano; "Essential technique for HACCP. From sterilizing to monitoring (HACCP hissu gijutsu. sakkin kara monitaringu made)" , Saiwaishobo, Tokyo, Japan, 1999, pp.6-11.

4) H. Hosaka; "Introduction to food engineering -The basic knowledge and applied operation- (shokuhin kougaku nyumon -kiso to sousa-)” , Kagakukogyosha, Kanagawa, Japan, 1972, pp.305-308.

5) H. Hayashi, T. Horiuchi, K. Wani; "Basic food engineering (kiso shokuhin kougaku)" , Tokyo, Japan, 1996, pp.49-55.

6) T. Itoh; "Production of dairy products (nyuseihin seizougaku)” , Korinsha, Tokyo, Japan, 2004, pp.376-384.
7) Japan dairy council; "Dairy products production guide by dairy faermer (rakunouka niyoru nyuseihin seizou gaido)”, Japan dairy council, Tokyo, Japan, 2006, p.19.

8) K. Nishinari, M. Mizukoshi, N. Kitahata; "Food Hydrocolloids: Development And Applications” , CMCbooks, Tokyo, Japan, 2007, p.129, pp.132-133, 344-345.

9) T. Hanai; "Heterogenous structure and dielectric constant (fukinshitsu kouzo to yudenritsu)" , Yoshiokashoten, 2000. pp.19-40, 83-90, 121-126, 204-218.

10) K. Sato, T. Furukawa, Y. Takeda, M. Takahashi, T. Matsumoto, T. Shimada; "Apply physical properties (ouyou bussei)" , Ohmsha, Tokyo, Japan, 1991, p.168-170.

11) H. Matsumura; "Basic physical properties of fine particles dispersion system (biryushi bunsankei no kisobussei)" , The chemical society of Japan, Tokyo, Japan, 2007.

12) A. Kitahara, K. Furusawa, M. Ozaki, H. Oshima, "Zeta potential -Physical chemistry of the interface of fine particles- (Zeta denni -Biryushi kaimen no butsuri kagaku-)" , Scientist-press, Tokyo, Japan, 1994, pp.3-5.

13) H. Sasaki; "Electrokinetic Phenomena of Gas Bubbles and Gas / Liquid Interface (1) Gas Systems.” (in Japanese). Bulletin of the Institute for Advanced Materials Processing of Tohoku University, 49, 79-88 (1993).

14) S. Segawa, Y. Mitani, K. Ohgaki, "Surface Behavior and Kinetic Analysis of Macromolecules Separated from Beer in Aqueous Solution” (in Japanese), JCEJ, 24, 649-653 (2000).

15) A.Phianmongkhol, J. Varley; $\zeta$ potential measurement for air bubbles in protein solutions, J Colloid Interface Sci, $\mathbf{2 6 0}$, 332-338 (2003).

16) M. C. Zaghdoui, M. Lallemand; Study of the behavior of a bubble in an electric field: steady shape and local fluid motion, Int. J. Therm. Sci., 39, 39-52 (1999).

17) H. Inokuchi; "Electromagnetism (denki jiki)" , The chemical society of Japan, Tokyo, Japan, 1991, p.220-230.

18) D. Kuroiwa; "The dielectric behavior of snow cover" (in Japanese), Low temperature science, 8, 1-57 (1951).

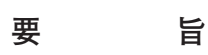

誘電特性は試料の構造, 組成, 相, 温度などの物理 的な要因と関連がある。そのため，これらの物性を利 用した測定法は試料の構造を把握する有効な手段とな る.また，この測定法では非破壊測定が可能である. この研究において, 我々はヨーグルト中の気泡が誘電 特性 (複素静電容量)に及ぼす影響を調べた。ベースヨー グルトに気泡を分散させることにより試料を準備し, ヨーグルト内の気泡量や気泡サイズが誘電特性に及ぼ す影響を検討した。その結果，ヨーグルト内の気泡量 
の増加に伴って静電容量は増加した。ささら、ヨーグ ルト内の気泡径の減少に伴って静電容量は増加した。 これは, 気一液界面に打ける界面動電現象が静電容量 の増加に寄与していると考えられる。一方, $50 \mathrm{~Hz}-1$ $\mathrm{MHz}$ 範囲でベースヨーグルトと気泡含有ヨーグルトの 複素静電容量の測定を行い，これらの測定值を基に
Cole-Cole プロットを描いたところ，両サンプルの円弧 の大きさに明瞭な違いが見られた. Cole-Cole プロット の円弧部分の周波数範囲内では, 空気含有ヨーグルト の静電容量は, 常にベースヨーグルトよりも大きかっ た. 以上の結果から, 誘電特性の測定によりヨーグル 卜内の気泡を定量化できる可能性を示すことができた。 